ISSN 0258-7122

Bangladesh J. Agril. Res. 37(2): 185-194, June 2012

\title{
STANDARDIZATION OF PROTOCOL FOR AGROBACTERIUM- MEDIATED TRANSFORMATION IN POTATO (Solanum tuberosum L.)
}

\author{
M. M. H. MOLLA ${ }^{1}$, K. M. NASIRUDDIN ${ }^{2}$, M. AL-AMIN ${ }^{2}$ \\ M. S. HAQUE ${ }^{1}$ AND MANIRUZZAMAN ${ }^{1}$
}

\begin{abstract}
The experiment was conducted at the Laboratory of Biotechnology, Biotechnology Division, Bangladesh Agricultural Research Institute, Gazipur1701 during July 2007 to June 2008. An efficient and reproducible protocol for the production of transgenic potato plants was developed by inoculating internode explants of potato with Agrobacterium tumefaciens strain LBA4404 carrying a binary vector pBI121 having one reporter gene $(g u s)$ and selectable marker gene (nptII) resistant to Kanamycin. The transformation experiment was done by optimizing two important parameters names infection time and cocultivation period. Most of the explants produced shoots within 21 days on 5 $\mathrm{mg} / \mathrm{l}$ Zeatin riboside (ZR) and $50 \mathrm{mg} / \mathrm{l}$ Kanamycin supplemented MS medium without introducing callus. The infected explants produced 8.27 and 6.42 shoots in Asterix and Diamant varieties, respectively within 21 days. Transgenes were confirmed by molecular analysis. DNA from well established rooted plants confirmed nptII positive through PCR analysis. The transformation rates were 28.97 and 24.37\% in Asterix and Diamant, respectively. Putative transformed plants of Diamant and Asterix varieties produced roots in $1 / 2 \mathrm{MS}$ medium supplemented with 50/mg Cefotaxim, 50 mg/l Kanamycin and 0.5 mg/l IBA.
\end{abstract}

Keywords: Potato, Agrobacterium transformation, nptII gene, internode explant

\section{Introduction}

Potato (Solanum tuberosum L.) belongs to the family Solanaceae is used as the most important food for a large number of people in the world. In Bangladesh, potato represents about $53 \%$ of the total edible vegetables. It is the most important non-cereal food crop and ranks fourth in terms of total global food production after maize, wheat and rice (Chakraborty et al., 2000). Potato is usually propagated asexually by means of tubers. Potato growers produced 320.71 million tones of potato annually from 19.26 million hectares of land (http//:www.potato 2008.org@FAO2007). In Bangladesh, about 6.65 million tons of potato produced from 0.402 million hectares of lands with an average yield of $16.53 \mathrm{t} / \mathrm{ha}$ (BBS, 2009). However, this yield is much lower than that of many potato growing countries of the world. Lack of high yielding varieties, pest and disease infestation, shortage of quality seed and environmental stresses are the

${ }^{1}$ Biotechnology Division, Bangladesh Agricultural Research Institute (BARI), Gazipur1701, ${ }^{2}$ Deptt. of Biotechnology, Bangladesh Agricultural University (BAU), Mymensingh. 
major constraints for the low yield of potato in Bangladesh. Moreover the crop losses occur $30-40 \%$ due to pest and diseases infestation. It may turn even $100 \%$ if the crop is attacked during the early stage (Hossain, 1997). It is now evident that to overcome the constraints of potato production, improvement of this crop by any means is an essential task (Fraley, 1983). The genetic transformation provides an exciting new technology to supplement traditional crop improvement and accelerate the development of new plant varieties against diseases, pests, and environmental stresses. Agrobacterium-mediated transformation has become the most useful method for the introduction of foreign genes into plant cells and the subsequent development of transgenic plants (Gustavo et al., 1998) against the biotic and abiotic stresses. Thus the present work has been undertaken to standardize the transformation protocol for potato in accordance with the optimization of pre-culture and co-cultivation period for Agrobacteriummediated genetic transformation, so that the gene of interest can be inserted efficiently in the economically important potato varieties of Bangladesh.

\section{Materials and Method}

\section{Plant materials}

The internode explants of two potato varieties viz., Diamant and Asterix were used as plant materials in this experiment.

\section{Agrobacterium strain and plasmid}

Agrobacterium tumefaciens strain LBA4404 with the binary plasmid pBI121 was used for this study. The binary vector pBI121 has the background of pBIN19. It contains a reporter gene GUS ( $\beta$-glucurunidase) driven by a CaMV35S promoter and NOS terminator. In addition, it has a selectable merker gene nptII fused between NOS terminator. It encodes for neomycin phosphotransferase that confers kanamycin resistance (Herrera-Estrella et al., 1983). Two culture media YMB (Yeast extract Mannitol Broth) and LB (Luria Broth) were used for the Agrobacterium strain. One for maintaining Agrobacterium stock and the other for the infection of explants. For maintenance, on single colony from previously maintained Agrobacterium stocks was streaked into freshly prepared Petri dish containing YMB medium having Kanamycin. The Petri dish was sealed with Para film and kept in the incubator at $28^{\circ} \mathrm{C}$ for at least 48 hours. This was then kept at $4^{\circ} \mathrm{C}$ to check over growth. Such culture of Agrobacterium strain was thus ready to use for liquid culture. The culture was sub-cultured regularly at each week in freshly prepared medium to maintain the stock. For infection, single streak was taken in an inoculation loop and was inoculated in a conical flask containing liquid LB medium with $50 \mathrm{mg} / \mathrm{l}$ Kanamycin. The culture was allowed to grow at $28^{\circ} \mathrm{C}$ to get optimum population of Agrobacterium for infection and co-cultivation of explants. 


\section{Media used}

For preparation of explants, instant MS (1962) medium including vitamins and minerals (4.4 g/l) (Duchefa, Netherlands) was used to prepare explants of potato for transformation work. Instant MS medium ( $4.4 \mathrm{~g} / \mathrm{l})$ supplemented with growth hormone ( $5 \mathrm{mg} / \mathrm{l} \mathrm{ZR,} 1 \mathrm{mg} / \mathrm{l} \mathrm{IAA}, 3 \mathrm{mg} / \mathrm{l} \mathrm{GA}$ and $50 \mathrm{mg} / \mathrm{l}$ Acetosyringone), 20 $\mathrm{g} / \mathrm{l}$ sucrose and $2 \mathrm{~g} / \mathrm{l}$ gel rite were used for co-cultivation medium. Filter sterilized ZR was added under laminar air flow cabinet. After co-culture, the explants were washed several times with sterile distilled water with gentle shaking until no opaque suspension was seen. The infected explants were finally washed for 3 minutes in MS liquid medium supplemented with $400 \mathrm{mg} / \mathrm{l}$ Cefotaxime. For post cultivation and shoot differentiation, MS medium supplemented with $5 \mathrm{mg} / \mathrm{l} \mathrm{ZR}$, $1 \mathrm{mg} / \mathrm{l} \mathrm{IAA}, 3 \mathrm{mg} / \mathrm{l} \mathrm{GA}_{3}, 50 \mathrm{mg} / \mathrm{l}$ Kanamicin, 200 mg/l Carbenecillin, $20 \mathrm{~g} / \mathrm{l}$ sucrose and $2 \mathrm{~g} / \mathrm{l}$ gel rite were used. IAA $(1 \mathrm{mg} / \mathrm{l})$ and $\mathrm{GA}_{3}(3 \mathrm{mg} / \mathrm{l})$ were used following Cearley and Bolyard (1997). To eliminate untransformed tissues, the regenerating explants were sub-cultured after 2-3 times on fresh regeneration medium initially with $50 \mathrm{mg} / \mathrm{l}$ Kanamycin. The concentration of Kanamycin was increased every fortnight when fresh subculture was made until its level reached $100 \mathrm{mg} / \mathrm{l}$. During each sub-culture the dead and deep brown tissues were discarded and green shoots were sub-cultured in a fresh medium containing the next higher concentration of Kanamycin. For root induction, 1/2MS medium supplemented with $50 \mathrm{mg} / \mathrm{l}$ Cefotaxime, $50 \mathrm{mg} / \mathrm{l}$ Kanamycin and 0.5-1.0 mg/l IBA were used.

\section{Infection and incubation}

The Agrobacteria grown in liquid LB medium was used for infection and incubation maintaining the optical density of $\mathrm{OD}_{600}=0.6$ to get suitable and sufficient infection of explants. For infection, the explants were dipped in the Agrobacterium suspension for 20, 30, 40 minutes and co-cultivation for 2, 3 and 4 days. Infection medium was prepared by adding liquid bacterial culture with liquid MS in an appropriate ratio and acetosyringone $50 \mathrm{mg} / \mathrm{l}$ was added to enhance bacterial activities.

\section{Data recording and analysis method}

The experiment was laid out in factorial CRD having 7 replications. Each Petri dish containing 7 explants was considered as a single replication. Data were recorded - responsive explants (\%), days required for shoot initiation, number of shoots per explant, length of visible shoots at 21 days, number of visible leaves at 21 days, diameter of visible shoot at 21 days and regeneration frequency and transformed plants. Data were analyzed using MSTAT-C program. Differences among the means were compared following DMRT at 5\% and $1 \%$ levels of 
significance. The percentage data were subjected to appropriate transformation according to Gomez and Gomez (1984).

\section{Isolation of plant genomic DNA}

Genomic DNA was isolated from non-transformed plant and transformants (particularly from leaf tissues) using the methods of EZ 10 spin column DNA isolation kit (Biobasic, Canada). Approximately $100 \mathrm{mg}$ of leaf sample was collected from transformed plants and was ground with liquid nitrogen. All steps for the DNA extraction were done according to the manufacture's instructions.

\section{PCR reactions}

The presence of $n p t I I$ gene in potato genomic DNA was analyzed using PCR. For the detection of the nptII coding sequence, DNA was subjected to PCR using forward and reverse primer comprising 5'-CATTAGTCCATGCAAGTT T-3' and 5'-AAGATTATACCGAGGTAT G-3', respectively (Sigma,USA). All primers were used at a concentration of $100 \mathrm{pmol} / \mu \mathrm{l}$. Master mix for PCR was prepared using standard protocol. The number of cycles used for $n p t I I$ gene was 29. The amplified DNA was run on $1.0 \%$ agarose gel and stained with ethidium bromide $(0.05 \mu \mathrm{g} / \mathrm{ml})$. To confirm the transformation, DNA was isolated using DNA isolation EZ-10 spin column genomic DNA isolation kit (Bio Basic, Canada) from putative transformed plants of high dose $(100 \mathrm{mg} / \mathrm{l})$ Kanamycin exposed plants. Genomic DNA from non-transformed plants was also isolated using the same kit. The quality of the plant DNA was confirmed by a positive control PCR reaction. Fifty putatively transformed plants were tested for $n p t I I$ gene.

\section{Results and Discussion}

Results presented in Table 1 show that all the explants responded equally to all treatments. Days required for shoot appearance, length of shoot, diameter of shoot, and no. of leaves per shoot varied among the treatments but differences were not significant. Number of shoots per explant significantly influenced due to variety, infection time and co-culture period

Internode explants of variety Asterix produced the highest number of shoots (9.50) per explant when treated as 30-minute infection and 3-day co-culture followed by 20- minute infection with same co-culture period (9.35). which was statistically identical. On the other hand, the lowest number of shoots per explant (5.25) was recorded from the variety Diamant with 40-minute infection and 4day co-culture (Fig. 1). Beaujean et al. (1998) reported that 30-minute infection

and 3-day co-culture of internode explants of potato cultured in MS medium supplemented with ZR $0.8 \mathrm{mg} / \mathrm{l}$ produced 7-9 shoots per explant. Winzler et al. (1989) reported that 4-day pre-treatment of tissues and 3/4-day co-culture is common to all Agrobacterium base gene transfer system. 


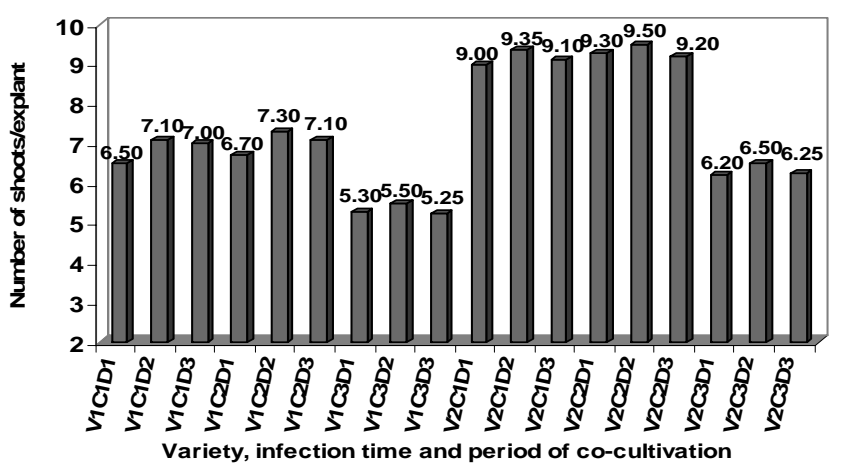

Fig. 1. Effect of variety, infection time and co-culture period on number of shoot production per explant at 28 days.

Where, $\mathrm{V}_{1}=$ Diamant, $\mathrm{V}_{2}=$ Asterix, $\mathrm{C}_{1}=$ Infection time $(20 \mathrm{~min}$. $), \mathrm{C}_{2}=$ Infection time (30 min.), $\mathrm{C}_{3}=$ Infection time (40 min.), $\mathrm{D}_{1}=$ Co-culture period (2 days), $\mathrm{D}_{2}=$ Co-culture period (3 days), $\mathrm{D}_{3}=$ Co-culture period (4 days).
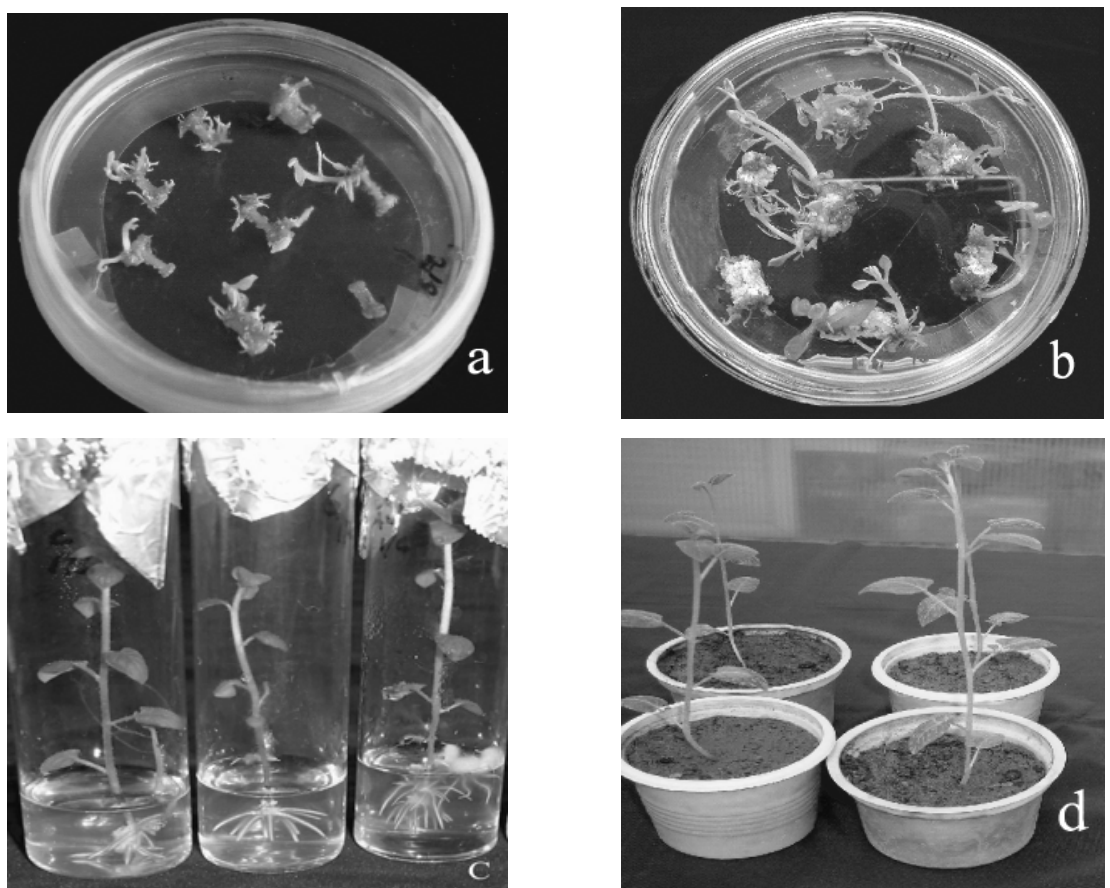

Plate 1: (a) Shoot induction in selection medium at 14 days, (b) Shoot induction in selection medium at 28 days, (c) In vitro transformed rooted plantlets at 28 days cv. Asterix, (c) Ex vitro established plants. 
Regeneration frequency percent was significantly influenced due to the effect of variety, infection time, and co-culture period which lay in between 80.43 to $100 \%$. The maximum regeneration frequency percent $(100 \%)$ was recorded in 30-minute infected explants of variety Asterix with 3-day co-culture (Table 1, Plate $1 \mathrm{a}, \mathrm{b})$. On the other hand, the minimum regeneration frequency percent (80.43\%) was recorded in 40-minute infected explants of variety Asterix with 4day co-culture. The reason for lowest regeneration frequency at 40-minute infection might be due to bacterial over growth in the surface of the explants. Gustafson et al. (2006) obtained 67\% regeneration frequency in stem explants of potato from MS medium supplemented with $0.1 \mathrm{mg} / \mathrm{l} \mathrm{IAA}+0.1 \mathrm{mg} / \mathrm{l} \mathrm{ZR}+5$ $\mathrm{mg} / \mathrm{l}$ Kanamycin $+300 \mathrm{mg} / \mathrm{l}$ Cefotaxim. Beaujean et al. (1998) stated that internode explants of potato with 30-minute infection and 3-day co-culture performed $90 \%$ regeneration frequency.
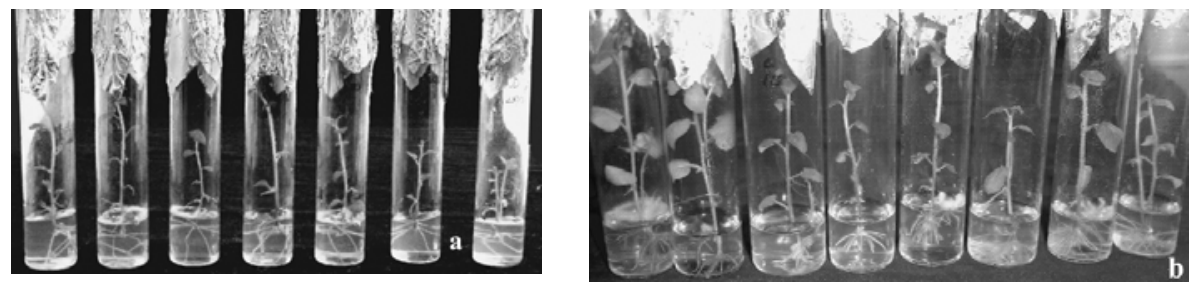

Fig. 5. Kanamycin selected transformed plants at 21 days (a) var. Diamant (b) var. Asterix

PCR analysis revealed that putative transformed plants displayed 700 bp size band (Fig. 6). Primer sets designed to represent the positive control template which also showed 700 bp band (Fig. 6). The genomic DNA from nontransformed control potato plants did not show any band in PCR reaction (Fig. 6). Rooting on selection (high Kanamycin dose) medium was found to be a good indicator of transformation (Fig. 5a, 5b), as $100 \%$ of rooted shoots were positive when tested by PCR which was missing in non transformed control plant (Table 2, Fig. 6). The above results indicated that nptII gene is conserved in respective region of the plasmid.

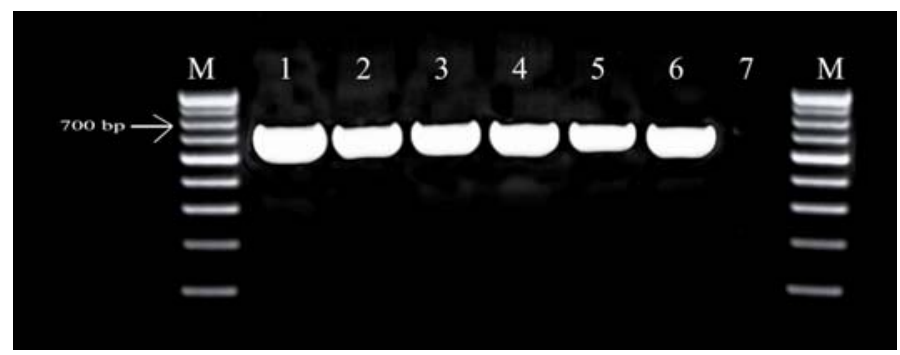

Fig. 6. Detection of $n p t I I$ gene by PCR from genomic DNA of transformed potato: M= DNA ladder, Lane 1= positive control, Lane 2-6 = PCR product of transformed plants. Lane 7= negative control. 
Table 1. Effect of varieties, infection time and co-cultivation period on shoot regeneration of potato.

\begin{tabular}{|c|c|c|c|c|c|c|}
\hline Treatment & $\begin{array}{c}\text { Responsive } \\
\text { explants } \\
\text { (\%) }\end{array}$ & $\begin{array}{l}\text { Days required } \\
\text { for shoot } \\
\text { appearance } \\
\text { (day) }\end{array}$ & $\begin{array}{l}\text { Length of } \\
\text { shoot } \\
(\mathrm{cm})\end{array}$ & $\begin{array}{c}\text { No. of leaves } \\
\text { /shoot }\end{array}$ & $\begin{array}{l}\text { Shoot } \\
\text { diameter } \\
(\mathrm{mm})\end{array}$ & $\begin{array}{l}\text { Regeneration } \\
\text { frequency (\%) }\end{array}$ \\
\hline Diamant $\times$ 20-min. $\times$ 2-day & 100 & 20.40 & 3.10 & 2.90 & 8.30 & $89.13 \mathrm{~g}$ \\
\hline Diamant $\times 20$-min. $\times$ 3-day & 100 & 21.50 & 2.75 & 2.70 & 8.40 & $97.39 \mathrm{c}$ \\
\hline Diamant $\times 20$-min. $\times$ 4-day & 100 & 21.80 & 2.80 & 2.80 & 8.20 & 81.541 \\
\hline Diamant $\times 30$-min. $\times 2$-day & 100 & 20.90 & 2.74 & 2.85 & 8.40 & $94.68 \mathrm{~d}$ \\
\hline Diamant $\times$ 30-min. $\times$ 3-day & 100 & 21.30 & 2.75 & 275 & 8.80 & $94.90 \mathrm{~d}$ \\
\hline Diamant $\times$ 30-min. $\times$ 4-day & 100 & 22.25 & 2.60 & 2.65 & 8.40 & $90.47 \mathrm{f}$ \\
\hline Diamant $\times$ 40-min. $\times 2$-day & 100 & 21.90 & 2.85 & 2.85 & 8.25 & $88.49 \mathrm{~g}$ \\
\hline Diamant $\times$ 40-min. $\times$ 3-day & 100 & 22.40 & 2.00 & 2.50 & 8.30 & 90.73 ef \\
\hline Diamant $\times$ 40-min. $\times$ 4-day & 100 & 22.00 & 2.20 & 2.60 & 8.10 & $82.33 \mathrm{k}$ \\
\hline Asterix $\times$ 20-min. $\times$ 2-day & 100 & 19.70 & 2.90 & 2.80 & 9.20 & $87.62 \mathrm{~h}$ \\
\hline Asterix $\times 20$-min. $\times 3$-day & 100 & 18.25 & 3.56 & 3.35 & 9.50 & $98.00 \mathrm{c}$ \\
\hline Asterix $\times$ 20-min. $\times$ 4-day & 100 & 19.90 & 2.90 & 2.75 & 9.40 & $83.42 \mathrm{j}$ \\
\hline Asterix $\times 30$-min. $\times 2$-day & 100 & 19.85 & 2.85 & 2.75 & 9.40 & $99.00 \mathrm{~b}$ \\
\hline Asterix $\times 30$-min. $\times 3$-day & 100 & 18.40 & 3.65 & 3.30 & 9.80 & $100.00 \mathrm{a}$ \\
\hline Asterix $\times$ 30-min. $\times$ 4-day & 100 & 19.65 & 3.35 & 2.80 & 9.60 & $89.23 \mathrm{~g}$ \\
\hline Asterix $\times$ 40-min. $\times 2$-day & 100 & 19.25 & 3.50 & 2.90 & 9.10 & $85.19 \mathrm{i}$ \\
\hline Asterix $\times$ 30-min. $\times$ 3-day & 100 & 19.00 & 3.50 & 2.90 & 9.30 & $91.23 \mathrm{e}$ \\
\hline Asterix $\times 30$-min. $\times$ 4-day & 100 & 20.10 & 2.50 & 2.73 & 9.10 & 80.431 \\
\hline $\mathrm{CV}(\%)$ & & 8.9 & 6.86 & 8.03 & 3.93 & 4.75 \\
\hline
\end{tabular}

Means bearing same letters do not differ significantly at 1\% level of probability, - = Absent. 
Table 2. Transformants ( $T_{1}$ and $T_{2}$ generation) identification from high doses Kanamycin tested plants.

\begin{tabular}{l|cc|c|c}
\hline Variety & \multicolumn{2}{|c|}{ No. of putative transgenic plants } & $\begin{array}{c}\text { DNA isolation } \\
\text { and PCR test } \\
\text { for nptII gene }\end{array}$ & $\begin{array}{c}n p t I I \text { positive } \\
\text { (\%) }\end{array}$ \\
\cline { 2 - 3 } & $\mathrm{T}_{1}$ generation & $\mathrm{T}_{2}$ generation & 56 & 24.69 \\
Diamant & 84 & 186 & 56 & 28.97 \\
Asterix & 112 & 256 & 56 \\
\hline
\end{tabular}

PCR amplification confirmed nptII gene both in the $\mathrm{T}_{1}$ and $\mathrm{T}_{2}$ generation. The nptII gene has been stably integrated to the potato genome and shown the appropriate bands after PCR amplification. Transformation rate was recorded 24.69\% and $28.97 \%$ against nptII gene in the Diamant and Asterix potato variety respectively (Table 2). This result is in agreement with the findings of Beaujean et al. (1998), Sarker et al. (2002) and Gustafson et al. (2006).

Table 3. Effects of different combinations of phytohormone in $1 / 2$ MS medium on root initiation of transgenic shoot of potato.

\begin{tabular}{|c|c|c|c|}
\hline Treatment & Varieties & $\begin{array}{l}\text { No. of shoots } \\
\text { showing root } \\
\text { initiation }\end{array}$ & $\begin{array}{l}\text { Root initiation } \\
\qquad(\%)\end{array}$ \\
\hline \multirow{2}{*}{$\begin{array}{l}\text { 1/2MS, 50mg/l Cefotaxime, } 50 \\
\text { mg/l Kanamycin and } 0.0 \text { IBA }\end{array}$} & Diamant & $4^{c}$ & $20.0^{\mathrm{c}}(25.61)$ \\
\hline & Asterix & $6^{\mathrm{b}}$ & $30.0^{\mathrm{b}}(32.04)$ \\
\hline \multirow{2}{*}{$\begin{array}{l}\text { 1/2MS, 50mg/l Cefotaxime, } 50 \\
\text { mg/l Kanamycin and } 0.5 \mathrm{mg} / \mathrm{l} \\
\text { IBA }\end{array}$} & Diamant & $20^{a}$ & $100.0^{\mathrm{a}}(86.82)$ \\
\hline & Asterix & $20^{\mathrm{a}}$ & $100.0^{\mathrm{a}}(86.82)$ \\
\hline \multirow{2}{*}{$\begin{array}{l}\text { 1/2MS, 50mg/l Cefotaxime, } 50 \\
\text { mg/l Kanamycin and } 1 \mathrm{mg} / \mathrm{l} \\
\text { IBA }\end{array}$} & Diamant & $20^{\mathrm{a}}$ & $100.0^{\mathrm{a}}(86.82)$ \\
\hline & Asterix & $20^{\mathrm{a}}$ & $100.0^{\mathrm{a}}(86.82)$ \\
\hline CV( \%) & - & 4.57 & 6.51 \\
\hline
\end{tabular}

Means bearing same letters do not differ significantly at $1 \%$ level of probability, Data within parentheses represents the arcsine transformed values.

Rooting of transgenic shoots was influenced due to different concentrations $(0,0.5,1.0 \mathrm{mg} / \mathrm{l})$ of IBA. $1 / 2 \mathrm{MS}$ medium supplemented with $0.5-1.0 \mathrm{mg} / \mathrm{l}$ IBA along with $50 \mathrm{mg} / \mathrm{l}$ Cefotaxime and $50 \mathrm{mg} / \mathrm{l} \mathrm{Kanamycin} \mathrm{showed} \mathrm{the} \mathrm{excellent}$ performance for root induction of transgenic potato shoots (Table 3). Cent percent (100\%) transgenic shoots produced root in these media which were statistically identical (Table 3). 


\section{Conclusion}

Explants infection for 30-minute with 3-day co-culture produced maximum shoots in Asterix and Diamant varieties, respectively within 18-21 days in $5 \mathrm{mg} / \mathrm{l}$ zeatin riboside and $50 \mathrm{mg} / \mathrm{l}$ Kanamycin supplemented MS medium. DNA from well established rooted plants confirmed nptII positive through PCR analysis.

\section{Acknowledgement}

Authors are thankful to the authority of USAID funded Horticulture Research Centre Strengthening Project, Bangladesh Agricultural Research Institute, Gazipur-170 to provide financial support for this study.

\section{References}

BBS. 2009. Bangladesh Bureau of Statistics. Ministry of Planning. Govt. of the People's Republic of Bangladesh, Dhaka. p 64.

Beaujean A., R. S. Sangwan, A. Lecardonnel and B. S. Sangwan Norreel.1998. Agrobacterium-mediated transformation of three economically important potato cultivars using sliced internodal explants: an efficient protocol of transformation. $J$. Expt. Bot. 49:1589-1595.

Cearley, J. A. and M. G. Bolyard. 1997. Regeneration of Solanum tuberosum cv. Katahdin from leaf explants in vitro. Am. Potato J. 74(2):125-129.

Chakraborty, S., N. Chakraborty and A. Datta. 2000. Increased nutritive value of transgenic potato by expressing a non-allergenic seed albumin gene from Amaranthus hypochondrioccus. Proc. Natl. Acad. Sci. USA, 97(7), March 28, 2000.

FAOSTAT. 2008. Production Year Book. Food and Agriculture Organization of the United Nations, Rome, Italy.

Fraley, R. T., S. G. Rogers, R. B. Horsch, J. S. Sanders, S. P. Flick, S. P. Adams, M. L. Bittner, L. A. Brand, C. L. fink, J. S. Fry, G. R. Galluppi, S. B. Goldberg, N. L. Hoffman and S. C. Woo. 1983. Expression of bacterial genes in plant cells. Proc. Natl. Acad. Sci., USA 80: 4803-4807.

Gomez, K. A. and A. A. Gomez. 1984. Statistical Procedures for Agricultural Research. John Willey and Sons. New York, 680 P.

Gustafson, V., S. Mallubhota, J. Macdonnel, M. Sanyal Bagchi, B. Chakravarty, G. Wang-Pruski, C. Rothwell, P. Audy, D. Dekoeyer, M. Siahbazi, B. Flinn and S. R. Gan. 2006. Transformation and plant regeneration from leaf explants of Solanum tuberosum L. cv. Shepody. Plant Cell Tissue and Org. Cult. 85: 361-366.

Gustavo A. de la Riva, J. G. Cabrera, R. V. Padron and C. A. Padro. 1998. Agrobacterium tumefaciens a natural tool for plant transformation. Electronic $J$. Biotechnol. 1(3):1-15.

Herrea-Esterella, L., A. Depicker, M. Van Montagu and J. Schell. 1983. Expression of Chimeric genes transferred into plant cell using a Ti-plasmid derived vector. Nature 303:209. 
Hossain, M. 1997. Purification and Antiserum Production of Potato X and Y Viruses on the Development of late blight in selected potato (Solanum tuberosum L.) Genotypes. Ph. D. thesis, University of Philippines, Las Benos, Philippines.

http://www.potato2008.org/en/comingsoon/index.html.

Murashige, T. and F. Skoog. 1962. A revised medium for rapid growth and bioassays with tobacco tissue culture. Physiol. Plantar. 15:473-497.

Sarker, R. H. and B. M. Mustafa. 2002. Regeneration and Agrobacterium-mediated genetic transformation of two indigenous potato varieties of Bangladesh. Plant Tissue Cult. 12(1):69-77.

Wenzler H., G. Mignery, G. May and W. Park. 1989. A Rapid and efficient transformation method for the production of large number of transgenic potato plants. Plant Sci. 63:79-85. 